\title{
The Great War in Comics Workings and Imagery
}

\author{
Maaheen Ahmed
}

\section{Remembering the Great War Today ... and Comics}

Within Europe and beyond, the centenary of the Great War began to be commemorated in 2014. As with any act of retelling history and re-creating memories, the events orchestrated around this centenary involve a certain tailoring of narratives and a process of forgetting that reflects more on the present milieu than the past. ${ }^{1}$ As noted by the sociologist and philosopher Elena Esposito, recent neurophysiological findings posit memory 'as a procedural capability realizing a constant recategorisation'. ${ }^{2}$ Especially relevant for this issue of European Comic Art is her claim that the memory of society as a whole is constituted, first of all, by the mass media and ruled by their always changing forms'. ${ }^{3}$ As emphasised by the articles in this issue, popular media during and after the First World War (music hall, illustrated magazines, comics, cartoons, pulps) were propagators of images that have persisted, often with altered significance, into our times.

Although veterans of the First World War are no longer alive, the memory of the war in the public sphere is mediated through what Pierre Nora has famously called lieux de mémoire, 'moments of history torn away from the movement of history, then returned; no longer quite life, not yet death, like shells on the shore when the sea of living memory has receded'. ${ }^{4}$ These include, but are not limited to, places

1 Elena Esposito, 'Social Forgetting: A Systems-Theory Approach', in Media and Cultural Memory, ed. Astrid Erll and Ansgar Nünning (Berlin: De Gruyter, 2008), 181-189 (185).

2 Ibid.

3 Ibid., 188.

4 Pierre Nora, 'Between Memory and History: Les Lieux de Mémoire', Representations 26 (1989), 7-24 (12). 
such as museums, cemeteries and battlefields associated with the war. The 'collapse of memory' of which the lieux de mémoire are indicative is linked to 'the tremendous dilation of our very mode of historical perception, which, with the help of the media, has substituted for a memory entwined in the intimacy of a collective heritage the ephemeral film of current events'. ${ }^{5}$ The consequent rise in experiential museums and re-enactments nowadays, which also dominate First World War commemorations, create what art historian Alison Landsberg calls 'prosthetic memories', 'memories that circulate publicly, are not organically based, but are nevertheless experienced with one's own body'. ${ }^{6}$

The Tower of London poppy memorial (17 July 2014 to 11 November 2014) captures the emphasis on both the visual and, to a lesser extent, the experiential. The spectacular installation of 888,246 ceramic poppies by ceramic artist Paul Cummins and theatre designer Tom Piper also demonstrates what can be termed the commercialisation of an historical event. ${ }^{7}$ Not only were the flowers sold to raise money for charities but the desire for durability (the possibility of attracting a larger number of spectators) overshadowed one of the main characteristics contributing towards the selection of the poppy as a (primarily British) symbol for the war: its fragile, transient essence. Indeed, the capitalist nature of commemoration ties in with the 'mix of sacred and profane' that historian Jay Winter sees accompanying commemorative practices. ${ }^{8}$ The sacred and the profane coexist on a more literal level in the imagery associated with the Great War, where Christian motifs were often used to express loss and suffering both on the front lines and on the home front. ${ }^{9}$ In addition, Winter's remark regarding the commercial facet of public commemoration, '[b]usiness remains business', is an important factor for comics, which depend on attracting readers and achieving viable sales figures. ${ }^{10}$

The emphasis on the visual - and by extrapolation, the sensorial - is likewise discernible in scholarship on the First World War, most notably in the historian Annette Becker's recent Voir la Grande Guerre: Un

5 Ibid., 8.

6 Alison Landsberg, 'America, the Holocaust, and the Mass Culture of Memory: Toward a Radical Politics of Empathy', New German Critique 71 (1997), 63-86 (66).

7 Although the installation was supposed to be removed on Armistice Day (11 November) in memory of the soldiers who had died, it was, against the wishes of the artists, prolonged due to its popularity.

8 Jay Winter, 'Sites of Memory and the Shadow of War', in Erll and Nünning, Media and Cultural Memory, 61-74 (67).

9 Annette Becker, Voir la Grande Guerre: Un autre récit (Paris: Armand Colin 2014), 133.

10 Winter, 'Sites of Memory', 67. 
autre récit [Seeing the Great War: A Different Story]. This is in keeping with Fredric Jameson's claim of a paradigmatic shift in descriptions of the past, moving from the Lukácsian historical novel and 'becom[ing] a vast collection of images, a multitudinous photographic simulacrum. ${ }^{11}$ In her preface, Becker points out how sounds, smells and images, unlike words, are distrusted, largely due to the nature of the propaganda dating from 1914 to 1918 that relied on evocative imagery to steer the public's emotions. ${ }^{12}$ Evocative stock images persist in comics on the First World War: gas, filth, decay, dismembered bodies and, of course, blood (aestheticised and commodified by the poppy in the Tower of London installation).${ }^{13}$ However, as shown by the contributions to this issue, stock images incorporate changing connotations in keeping with changing socio-political climates.

Comics themselves bring together visual and experiential elements since they combine images with the visual imitation of sound as well as a sense of time (albeit one based on ruptures rather than continuities). Since the 1990s, after the wide acclaim accorded to Joe Sacco's Palestine and Art Spiegelman's Maus, both comics autobiography and comics reportage have been on the rise. This is, in keeping with Jameson's words above, indicative of the return to more openly subjective, personal accounts of histories. Both tendencies - the autobiographical and the documentary - are discernible in comics on the First World War. However, in lieu of the realism dominating some of the more iconic comics on the war - such as Pat Mills and Joe Colquhon's Charley's War (1979-1985), Joe Sacco's scroll-like The Great War (2013) or even many of Jacques Tardi's comics (early 1970s onwards), which combine a somewhat playful graphic line with historically accurate details, increasingly fantastic renditions of the war, especially in the prolific field of Franco-Belgian comics production, are also acquiring prominence. ${ }^{14}$

11 Fredric Jameson, 'Cultural Logic of Late Capitalism', in Postmodernism, or, The Cultural Logic of Late Capitalism (Durham, NC: Duke University Press, 1990), 1-54 (18).

12 Ibid., 11.

13 To mention only two collections in English: Chris Duffy, ed., Above the Dreamless Dead: World War I in Poetry and Comics (New York: First Second, 2014); Jonathan Clode and John Stuart Clark, eds., To End All Wars: The Graphic Anthology of the First World War (London: Soaring Penguin, 2014).

14 E.g. David B., La lecture des ruines [Reading the ruins] (Marcinelle: Dupuis, 2001); Manu Larcenet, Une aventure rocambolesque de Vincent Van Gogh: La ligne de front [A fantastic adventure of Vincent Van Gogh: the front line] (Paris: Dargaud, 2004); Francis Porcel and Zidrou, Les Folies Bergère (Paris: Dargaud, 2012). This information is largely indebted to the following conference paper: Jean-Louis Tilleuil, 'La guerre 14-18 dans la BD: à quoi ça sert?' [The 14-18 war in comics: what is the point?], 14-18 en bande dessinée et en littérature de jeunesse [14-18 in comics and in children's literature] (3-4 
The recent increase in, and diversification of, First World War comics suggests the presence of a market for comics stories that are not limited to their traditional genres or characters. However, this also pushes traumatic memories closer to entertainment while serving specific political agendas (such as the assertion of national, and sometimes European, identities). ${ }^{15}$

\section{First World War Popular Imagery: Intertwined Functions and Constructions}

As Thierry Smolderen has described in detail, comics have come under a range of influences, from ancestors like Hogarth's broadsheets and Rodolphe Töpffer's romans en estampes to contemporary media with which they co-exist, such as magazines and the cinema. ${ }^{16}$ In the case of the First World War, illustrated magazines, using images for informative, satirical, ${ }^{17}$ propagandist and entertainment purposes, are likely to have transferred these functions, and the visual vocabulary associated with them, to comics (and vice versa). For instance, the journalistic, documentary purposes served by drawings, especially before the advent of photography persist in many comics based on historical events and figures. The intertwined satirical, propagandist and entertainment concerns are captured by expressionist images, demonising the enemy and the entire experience of war in an attempt both to capture the unrepresentability of trauma and to channel the reader's emotions. ${ }^{18}$

The interplay of the above four functions is brought out by the articles collected in this issue, which examine the intersection of parody and propaganda during the war years and the post-war decades (Benoît

June 2014, Namur). See also Vincent Marie, ed., La Grande Guerre dans la bande dessinée [World War I in comics] (Péronne: Historial de la Grande Guerre, 2009); Bruno Denéchère and Luc Revillon, 14-18 dans la bande dessinée: Images de la Grande Guerre de Forton à Tardi [14-18 in comics: images of World War I from Forton to Tardi] (Turquant: Cheminements, 2008).

15 See Andreas Huyssen, 'Present Pasts: Media, Politics, Amnesia', Public Culture 12(1) (2000), 21-38 (29).

16 Thierry Smolderen, Naissances de la bande dessinée: De William Hogarth à Winsor McCay [The origins of comics: from William Hogarth to Winsor McCay] (Brussels: Les Impressions Nouvelles, 2009).

17 Being, like comics themselves, the products of rapidly transforming modern times, magazines such as La Baïonnette (Paris, 1915-1920), Die Fliegenden Blätter (Munich, 1845-1944), Simplicissimus (Munich, 1895-1944, 1954-1967) and of course Punch or the London Charivari (London, 1841-2002) could be of particular relevance in this respect.

18 Depictions of Germans as Frankenstein or ape-like monsters were inspired by fantasy literature (Becker, Voir la Grande Guerre, 81-82). 
Glaude's 'Contextualising the Offendstadt Brothers' Wartime Comics and Their Reception'), later rewritings of the war to serve political agendas (Michael Scholz's 'The First World War and the German Revolution of 1918-1919 in East German Comics') and established popular culture formulas (Jean-Matthieu Méon's 'A War Like Any Other... Or Nobler? The Great War in the EC Comics') as well as reverberations of the clichés associated with the war beyond their original context (Ross Wilson's 'The Past and Present War').

Following a roughly chronological order, this issue begins with Glaude's article. Examining the context of French comics produced during the First World War, and focusing in particular on Louis Forton's Les Pieds nickelés, which was published in the highly successful Librairie Offenstadt magazine, L'Épatant, Glaude highlights the transfer of stories and types between comics and other forms of popular entertainment (popular imagery, music hall) as well as the increasingly heroic portrayals of the soldiers. In doing so, Glaude describes the success of the secular Offenstadt publications, which sought to cater to a broad audience ranging from adults to children and were - in spite of criticism of their secular stance and the German origin of the publishing family - far more popular than their more Catholic-oriented competition. L'Épatant in particular influenced generations of readers, growing up during the belle époque and the First World War, albeit in different ways, turning into a parody of the belle époque for the children growing up during the First World War.

Remaining within Europe but moving forward in time, Scholz's article delineates the attempt to develop a distinctive form of East German comics or picture stories [Bildgeschichten] from the 1950s onwards that aimed not merely to entertain their readers, like the much-belittled Western comics, but also to 'educate' them. Hence, under the German Democratic Republic, comics were once again instrumentalised for propagandist purposes.

Also focusing on First World War comics stories from the 1950s, but this time on comics published in the United States by EC Comics from 1951 to 1955, Méon traces the changing tone of the stories: starting with the generally more humanistic stance instilled in the comics under Harvey Kurtzman's editorship, the comics gradually moved on to more traditional mythologisations of the Great War, narrating the event in the vein of adventure stories. This change, Méon suggests, can be attributed not only to the change of editors but also to the introduction of the Comics Code (1954), which called for more conformist material. 
The last article in this issue, by Wilson, describes the changing signification of key images from the popular memory of the First World War in political cartoons since the end of the war and up to the present, focusing on the stereotyping and recycling of images (trenches, no man's land) and phrases ('a better 'ole', 'over the top') forming a popular memory of clichés that are then resurrected for contemporary concerns.

As suggested by the four articles, the different, partially interlinked, roles played by comics - entertainment, propaganda, satire, education - both feed on and feed into the vast but often repetitive realm of popular cultural memory. 'You may forget the gas and shells / You'll never forget the mademoiselles', goes a wishful line in one of the versions of 'Mademoiselle from Armentières'. ${ }^{19}$ If comics are any indication, it is the gas and the shells, not the women, that dominate the collective memory of the Great War. This memory is far closer to the imagery in the much shorter song 'If You Were the Only Boche in the Trench' (parody of 'If You Were the Only Girl in the World'): the 'chamber of horrors' involving an encounter with a weaponless German soldier results, in keeping with the customs of the times (from which material destined for children was not exempt ${ }^{20}$ ), in the violent death of the German. ${ }^{21}$ Although the image of the enemy has become more nuanced in the wake of the war, ${ }^{22}$ with soldiers on both sides shown as being forced into a pointless, bloody war against their will, the chamber of horrors, where nightmares become real, persists. However, even these nightmares, which are essentially personal, subjective experiences, contain a certain set of clichés that concretise the Great War for us but acquire changing meanings according to the times and contexts, simultaneously losing at least some of the significance originally attached to them. The currently popular use of fantasy for narrating the First World War - to take only one obvious example of such changes - can therefore be seen as not only reflecting distance from the actual

19 Ronald Herder, ed., 500 Best-Loved Songs (Mineola, NY: Dover Publications, 1997), 136. Here the song is titled "Hinky Dinky Parlay-Voo (Mademoiselle from Armentières)" Traditional World War One Song'. Martin Pengler's Soldiers' Songs and Slangs of the Great War (Oxford: Osprey Publishing, 2014) includes a far more violent and graphic version involving three German soldiers (330-333).

20 Becker, Voir la Grande Guerre, 78.

21 Pengler, Soldiers' Songs, 271.

22 Luc Revillon, De l'enjeu de victoire des illustrés de 1914-1918 à l'enjeu de mémoire des bandes dessinées contemporaines: évolution de l'image de l'ennémi' (From the issue of victory in the illustrated magazines from 1914-1918 to the issue of memory in contemporary comics: evolution of the image of the enemy) in Marie, La Grande Guerre dans la bande dessinée, 68-81. 
event but also as a means of breathing new life and relevance into familiar tropes.

As shown by the articles in this special issue of European Comic Art, tracking down such transformations and continuities can contribute towards a better understanding of the interplay of influences between comics, other forms of popular culture and collective memories that unfolds in the process of resurrecting (ghosts of) images, while also inevitably altering their connotations. Consequently, the more material processes of recategorisation that memory itself undertakes can also be mapped. ${ }^{23}$

This issue of European Comic Art was guest-edited by Maaheen Ahmed, with Martin Lund and Kees Ribbens.

Maaheen Ahmed is an FWO (Research Foundation - Flanders) postdoctoral fellow at Ghent University's English Department. Her current project focuses on the portrayal of troubled minds in personal and collective contexts in French- and English-language comics. Her first monograph on comics, Openness in Comics: Generating Meaning within Flexible Structures, will be published by the University Press of Mississippi in 2016. Her second project draws out the links between monstrous protagonists in comics and their counterparts in Romantic images and literature. Articles on comics have been accepted by journals such as the International Journal of Comic Art and the European Journal of American Studies. She has also contributed to Graphic History: Essays on Graphic Novels and/as History, edited by Richard Iadonisi as well as the Critical Survey of Graphic Novels, edited by Bart Beaty and Stephen Maynard.

Martin Lund, Linnaeus University and CUNY Graduate Center, holds a PhD in Jewish studies from Lund University in Lund, Sweden. Lund is currently a Swedish Research Council International Postdoc at Linnaeus University in Växjö, Sweden. His main research interests are religion and comics, the representation of race and ethnicity in popular culture, and the role that the specific ethno-racial and socio-political conditions of geographical place play in textual production. His current research focuses on representations of New York City in American comics. Lund has published articles and reviews in academic and 
popular science journals on a range of subjects. Recent and upcoming publications include articles for the Journal of Urban Cultural Studies, European Journal of American Studies, and Studies in Comics. Lund is also an editor of the Scandinavian Journal of Comic Art and a member of Sacred and Sequential, a collective of comics and religion scholars.

Kees Ribbens is Endowed Professor of Popular Historical Culture and War at Erasmus University Rotterdam. He is also senior researcher at NIOD Institute for War, Holocaust and Genocide Studies. His interest covers the history of the Second World War and the memories and representations of war and mass violence in the twentieth and twenty-first centuries. Notable publications include: Exhibiting the War: The Future of World War II Museums in the Netherlands (with Esther Captain, 2011); Oorlog op vijf continenten. Nieuwe Nederlanders \& de geschiedenissen van de Tweede Wereldoorlog (War on five continents: new Dutchmen and the histories of World War II) (with Joep Schenk and Martijn Eickhoff, 2008); Nationale identiteit en meervoudig verleden (National identity and plural past) (with Maria Grever, 2007) and Bewogen jaren. Zwolle in de Tweede Wereldoorlog (Stirring years: Zwolle in World War II, 1995). 